\title{
АНАЛИЗ ПРОБЛЕМЫ ФОРМИРОВАНИЯ ГРАЖДАНСКОЙ ГРАМОТНОСТИ НА РАЗНЫХ ЭТАПАХ РАЗВИТИЯ ОБЩЕСТВА
}

\section{ANALYSIS OF THE PROBLEM OF CIVIL LITERACY FORMATION AT DIFFERENT STAGES OF SOCIETY DEVELOPMENT}

\section{Vagilova}

A. Gayazov

Summary: The article analyzes the problems of the formation of civic literacy at different stages of the development of society. A historical excursion into the pedagogy of past centuries allows us to assert that in the process of the evolution of education and enlightenment thought, a huge experience of civic education and the formation of civic literacy of the individual was accumulated, which is of undoubted interest for the present. The idea of educating and becoming a citizen arose along with the emergence of state formations and was due to the urgent need to have law-abiding people loyal to the authorities, and later - to the state and public interest of the country.

Keywords: analysis, progress, civic education, literacy, citizenship, education, school, family.
$\mathrm{H}$ а ранних этапах человеческой истории имелось описание процессов культурного и исторического характера, которое, прежде всего, основывалось на использовании данных этнографического и археологического характера. Такие описанные факты позволяют современным исследователям понять основные явления и факты духовной и материальной культуры у разных народов мира на стадии их раннего развития. Несколько периодов, которые связаны с основными этапами исторического и общественного развития и становления общества могут выступать рубежами в развитии и становлении проблемы формирования гражданского воспитания и гражданской грамотности [1, с 17-20].

Развитие стандартов поведения молодежи еще во время племенных общин за 8-5 тысяч лет до нашей эры для всей общины было заботой. Прежде всего, развитию поведенческих стандартов способствовали разные средства, среди которых могут быть выделены участие в фестивалях и церемониях ритуального характера, в которых детей вовлекали в атмосферу эмоционального характера племенного образа жизни и племенных обычаев. Такие мероприятия способствовали выработке у детей подходящих ценностных ориентаций и идеалов. Кроме того, в тот исторический период достаточно часто применялись запреты ритуального характера: одобрения, запугивания и разного рода табу. Именно поэтому
Вагилова Внера Радиковна

Аспирант, Башкирский государственный университет, г. Уфра vneraa@mail.ru

Гаязов Альфис Суфиянович

д.n.н., профессор, Башкирский государственный университет, г. Уфа alfis@list.ru

Аннотация: В статье анализируется проблемы формирования гражданской грамотности на разных этапах развития общества. Исторический экскурс в педагогику прошлых веков позволяет утверждать, что в процессе эволюции образования и просветительской мысли был накоплен огромный опыт гражданского воспитания и формирования гражданской грамотности личности, представляющий несомненный интерес для современности. Идея воспитания и становления гражданина возникла вместе с появлением государственных образований и была обусловлена острой потребностью иметь законопослушных и преданных власти людей, позднее - государственному и общественному интересу страны.

Ключевые слова: анализ, прогресс, гражданское воспитание, грамотность, гражданственность, образование, школа, семья.

можно предположить, что в те дни также встречались зачатки таких понятий, как «обязанности и права».

В Древнем Китае (6-5 век до нашей эры) наибольшее влияние на развитие воспитательного мышления, а также образования и воспитания оказал Конфуций. Его идеи базировались, прежде всего, на отношениях между всеми гражданами государства, между людьми, которые принадлежали разным слоям общества, а также между государством и людьми. Как отмечается в научной статье Ван Гохуна и Л.И. Шерстовой, Конфуций уделял пристальное внимание человеческому моральному самопознанию. В преподавании Конфуция основным элементом, по мнению исследователей, был тезис о том, что неотъемлемой государственной предпосылкой блага является адекватное и качественное образование $[2$, c. 172-177].

К проблемам гражданского воспитания обращались многие философы Древней Греции. Первые философы вначале обратили свой взор на человека в целом, на проблемы его сущности, смысла жизни и т. д. Они искали идеалы доброго и прекрасного в человеке, давали людям представление о том, каким те должны быть, как относиться друг к другу, к законам, религии, государству.

Философские размышления о роли и месте воспита- 
ния человеческой гражданственности доносят до нас первые письменные источники древних цивилизаций. Труды таких древнегреческих ученых, как Сократ, Платон, Ксеновонт, Демокрит, Аристотель и пр. занимают наиболее заметное место в исследовании данного вопроса. Несмотря на то, что у философов древних цивилизаций отличались подходы к исследуемой проблеме, в их размышлениях можно наблюдать отчетливое стремление к тому, чтобы считать идеальным государственным гражданином того, кто полностью посвятил собственную жизнь служению интересам государства, готов к их защите и полностью предан им [3, с. 1-4].

Актуальность воспитания собственных граждан и формирования у них целой совокупности моральных качеств способствует тому, что государство станет местом, в котором совершаются нравственные действия. В философской мысли Цицерона выделяется совокупность качеств человека, которыми он должен обладать и которые он должен искоренить, чтобы в большей степени соответствовать гражданственности. Среди качеств, которыми человек должен обладать, Цицерон выделяет: верность своему делу, мягкий нрав, доброта, щедрость.

Можно утверждать, что потребность в формировании гражданской грамотности была зарождена еще в раннеклассовом обществе. В Древней Греции многие философы занимались основными проблемами политического воспитания. Политическое воспитание, прежде всего, было направлено на раскрытие смысла жизни, изучение проблемы природы человека и в целом на исследование человека. Как отмечается в научном исследовании Г.Е. Журавского, первые философы Греции искали основные идеалы красоты и добра в людях, а также давали им идеалистическое представление о том, какими должны быть люди, как они должны относиться к государству, религии, законам и другим людям [4, с. 110].

Образование молодежи, как считал ученик Сократа Ксенофонт (430-355/354 годы до нашей эры), не может являться вопросом индивидуального характера. В результате того, что целью образования молодежи считается создание совершенных граждан, оно должно контролироваться со стороны государства [5, с. 17-21].

Понимание содержания и целей школьного образования было заложено также Платоном (428/427-348/347 годы до нашей эры), который являлся учеником Сократа. Платон в сочинении «Законы» пишет о том, что образование представляет собой нечто, которое ведет от детского возраста к некой добродетели и заставляет индивида стремиться стать совершенным, идеальным гражданином, который может управлять и справедливо подчиняться людям [6, с. 210-212]. В то же время, в философской формулировке человека философом Аристотелем сказано, что человек выступает социальным существом, высшим уровнем добродетели которого является работа на благо государства от имени сограждан [7, с. 37-40].

Как писал Г.Е. Жураковский, еще Аристотель отмечал, что такая добродетель приобретается не через убеждение или обучение, а через привычку человека делать добрые дела. Исследователь также подчеркивает, что такая привычка формируется и начинает развиваться с детства, благодаря эффективно организованной благоприятной среды для человеческого воспитания [8, с. 174].

В Древнеримской педагогике одним из ключевых деятелей можно считать М.Т. Цицерона (106-43 годы до нашей эры). М. Цицерон рассматривал во многих собственных работах тему образования идеального гражданина. Прежде всего, исследователь стремился охарактеризовать того, кого можно назвать «хорошим человеком». Общая логика гражданского образования, предлагаемая М. Цицероном, была отражена в таких его работах, как «Об обязанностях», [9, с. 100] «О законах» [10, электронный ресурс]. В перечисленных работах исследователя выделены основные наставления из повседневной жизни, именно на них, в первую очередь, педагогическая повседневная деятельность должна опираться.

Таким образом, еще с древности присутствовал идеал разносторонней личности, который включал в себя определенные элементы гражданской грамотности. С течением времени этот идеал претерпел значительные изменения. На протяжении долгого времени исследователи видят реализацию гражданского долга как неотъемлемую часть личностного воспитания гражданина.

Наиболее высшим достоянием каждого человека, по словам Цицерона, считается выполнение общественных обязанностей, которые могут изменяться в зависимости от сферы деятельности, знаний, опыта и возраста. Как отмечает философ, достойное исполнение собственных обязанностей - это принятие мер на благо самого себя и общества, а также служение государство. Философ видит в исполнении собственных обязанностей «нравственную красоту человеческой жизни» [11, с. 26-33].

Актуальность воспитания собственных граждан и формирования у них целой совокупности моральных качеств способствует тому, что государство станет местом, в котором совершаются нравственные действия. В философской мысли Цицерона выделяется совокупность качеств человека, которыми он должен обладать и которые он должен искоренить, чтобы в большей степени соответствовать гражданственности. Среди качеств, которыми человек должен обладать, Цицерон выделяет: верность своему делу, мягкий нрав, доброта, щедрость $[12$, c. 26-33]. 
Сложившийся в античности идеал разносторонне развитой личности претерпевал в эпоху Возрождения существенные изменения. В Италии, колыбели европейского возрождения, главным в формировании гармонической личности было признано воспитание гражданина. Представители так называемого «гражданского гуманизма», обозначавшие его общественные функции, - Л. Бруни, Л. Валла, Л. Алберти - определяли основной функцией воспитания формирование человека, действующего на благо общества. Чуть позже Паоло Верджерио уточнил это размышление, отметив, что воспитание гражданина - дело отнюдь не только родительское, но прежде всего государственное. Реализацию гражданского долго гуманисты видели и в трудовой деятельности, которая стала рассматриваться как неотъемлемая часть воспитания личности гражданина.

Если в развитии Европы в эпоху средних веков самым характерным явлением было распространение и господство христианкой религии и ее идеологии, то в жизни большинства народов Ближнего и Среднего Востока аналогичную роль сыграло возникновение и распространение другой мировой религии - ислама. Он сыграл существенную роль при переходе от родовой общины к различным формам государственности.

В эпоху Просвещения на территории средневековых государств Закавказья, в частности, гениальный поэт Шота Руставели, который написал в то время своего «Витязя в тигровой шкуре» отстаивал право личности на свободу, идеи товарищества и сотрудничества людей, патриотизм, гражданственность.

Большие идеологические сдвиги эпохи Возрождения отразились и на педагогике того времени. Школа в некоторой степени освобождается от влияния церкви; усиливаются элементы светского образования.

Как известно, русская культура складывалась на основе двух начал - древней дохристианской культуры языческой Руси и христианства. Соответственно, и воспитание воинов включало в себя компоненты двух исторических культурных традиций, за столетия весьма переплетшиеся между собой и сформировавшие единую воинскую культуру.

Большое значение в Древней Руси придавалось военному делу. Экономически общины уже могли позволить себе содержать дружины - профессиональных воинов. По мнению известного русского историка педагогики П.Ф. Каптерева, древним славянам той эпохи больше всего подходила, модель воспитания, основанная на патриархальном семейном укладе с непререкаемым авторитетом отца, подчиненным положении детей, строгой домашней дисциплине. Очевидно, что подобное отно- шение воспитывалось и к власти.

Таким образом, в «Поучении» Владимира Мономаха впервые были сформированы нравственные основы воинского служения в православной Руси. Воинское служение в этом понимании - это борьба добра со злом, православный воин должен быть на стороне добра и заботиться не только о победе, но и о том, чтобы остаться благочестивым, сохранить праведность. Защита земли Русской и веры Православной становится главным смыслом воинского служения, ради которого можно отдать жизнь свою, но и забрать жизни врагов страны и веры.

Одной из вершин педагогической мыли того времени, был «Домострой» - сборник наставлений, свод правил, составленный известным деятелем из ближайшего окружения Ивана Грозного - попом Сильвестром. В Домострое нарисована картина русской жизни и семейного быта, кодекс норм поведения в отношениях мужа и жены, родителей и детей, хозяев и слуг, и всех их вместе к Богу и властям.

Интересен труд Епифания Славинецкого который перевел на русский язык книги Эразма Роттердамского «Гражданство обычаев детских», где разделил весть текст в форме диалога, который учит нормам бытового поведения, светскому образу жизни, манерам.

Педагогические труды Я.А. Коменского (1592 - 1670) включают в себя преобразование всего воспитания и обучения так, чтобы готовить будущих деятелей. Идеалом человека для Коменского является новый человек, владеющий вещами и собой. Таким человека делают научное образование, добродетель, благочестие.

Видным деятелем американского Просвещения был третий по счету президент Америки, автор проекта Декларации независимости Т. Джефферсон. В публичных выступлениях он призывал отказаться от практики посылать молодых американцев в Европу для получения образования, аргументируя это тем, что на чужбине едва ли можно научиться полезному для своей страны делу и за время учебы они отвыкают от родного языка и становятся далеки от родной почвы. Чувство Родины у молодого поколения переселенцев еще не сформировалось. При его активном участии была, разработана модель трехступенчатой общеобразовательной школы.

Серьезные изменения в политической, экономической, культурной жизни России, начавшийся еще в середине XVII в. и связанные с ее постепенным выходом из средневековой изоляции по отношению к Европе, продолжались и усилились в петровскую эпоху. По поручению Петра I и при его личном участии в 1972 году Ф. Прокопович составил «Духовный регламент», в его 
трактовке государственная, светская идея преобладает над религиозной, он хотел придать новой школе научный характер.

Другой важнейшей чертой образования стало преобладание сословия. Внутренняя политика Петра I характеризовалась стремлением возвышению дворянского сословия. В итоге все созданные государством средние и высшие школы предназначались в основном для детей дворян, готовившихся к занятию главных должностей в государственном аппарате, армии, на флоте, для руководства промышленностью и торговлей. В целом же для различных сословий создавались свои школы. Исключение составляло лишь крестьянство, ибо крестьянский труд, как считалось, не требовал какого-либо образования.

Школы, по мнению В.Н. Татищева, должны были формировать у учащихся светское сознание, воспитывать для жизненного благополучия, формируя «разумного эгоиста». В его понимании «разумный эгоизм» должен был предполагать в первую очередь осознание человеком самого себя, своего внутреннего мира, понимания, что ему во вред, а что на пользу, т.е. уметь различать добро и зло.

Развитие педагогической мысли и школьной практики в России 40-60 - х гг. XVIII в. неразрывно связано с именем М.В. Ломоносова. Ученый-энциклопедист был сторонником идеи переустройства общественной и личной жизни людей средствами правильно поставленного школьного образования, развивающего разум и способствующего совершенствованию нравов. Природу человека М.В. Ломоносов рассматривал иерархически: «нижняя», чувственная, эгоистическая и «высшая», патриотическая, гражданская. Отсюда и цели просвещения - научное образование человека, которое проводит к пониманию главенства общественной пользы над личными интересами. Художник и поэт М.В. Ломоносов был одержим мыслью создать российский по духу и содержанию университет и при нем гимназию, в которых могли бы учиться все желающие независимо от сословий.

B 60-80 - е гг. XVIII В., время правления Екатерины II, окончательно оформляется идея создания общеобразовательной школы для широких слоев населения, исключая крепостное сословие, с собственно педагогической, а не узкопрофессиональной и сословной, как в предшествующую эпоху, является целью воспитания. Программным документом, определившим направление государственной политики в области образования и просвещения второй половины XVIII в., стал так называемый «Наказ императрицы Екатерины Il». В этом документе закреплялось за каждым сословием строго отведенное ему место в общественной жизни: каждый человек должен был осознавать себя гражданином, преданным самодержавию, законопослушным. Задача формирования, так понимаемого, гражданина возлагалась на правильное воспитание. Екатерины ІІ считала, что надо прививать детям любовь к Отечеству, уважение к законам и правительству. Также императрица особое внимание обращала на качества личности воспитателя, который сам должен быть образцом истинной гражданственности.

Свои педагогические воззрения Н.И. Новиков изложил наиболее полно в трактате «О воспитании и наставлении детей» (1783). Воспитание должно включать В себе три основные части: физическое воспитание; нравственное, без которого ни один человек не может быть внутренне счастлив, душевен с близкими, в полной мере не станет хорошим гражданином, а также образование разума, которое необходимо человеку и гражданину для исполнения всех своих обязанностей.

В русской педагогике конца XIX - начала XX в. отражалось уважительное отношение к личности ребенка, его интересам и потребностям, стремление постигнуть его внутренний мир, создать условия для всестороннего развития были общими для различных педагогических течений рассматриваемого периода. Общим было и отрицательное отношение к сословности школ, утверждение, что каждый ребенок имеет право на полноценное образование, на развитие всех заложенных в нем сил и возможностей.

Воспитание гражданственности личности в значительной степени определяется объективным состоянием государства, уровнем развития демократии и гуманности в обществе, востребованностью гражданских качеств его членов. В свою очередь, уровень развития общества во многом зависит от позиции каждого человека. Основная цель гражданского воспитания состоит в формировании в человеке нравственных идеалов общества, чувства любви к Родине, потребности в деятельности на благо общества и т.п. Гражданское воспитание тесно связано с нравственным воспитанием, патриотическим воспитанием и правовым воспитанием. Образовательные учреждения как наиболее стабильные социальные институты могут внести значительный вклад в создание условий для воспитания нравственно и физически здорового, социально активного подрастающего поколения. Один из путей - формирование гражданской грамотности учащихся.

В современных российских условиях развития наблюдается стремление государства к построению гражданского общества, которое будет, прежде всего, базироваться на развитой рыночной экономике, принципах демократии с заметной ролью информации в системе общественных отношений в производственной сфере. 


\section{ЛИТЕРАТУРА}

1. Вагилова В.Р. Прогрессивное развитие понятия гражданской грамотности на разных этапах развития общества // StudNet, 2020. № 9. С. 17-21.

2. Шерстова Л.И., Ван Гохун. Конфуцианские принципы нравственного воспитания человека и их значения для современности // Вестн. Том. гос. ун-та. 2017. №425. С. 172-177.

3. Кошелева И.В. Развитие педагогики и образования в античном мире // Проблемы и перспективы развития образования : материалы ІХ Междунар. науч. конф. (г. Краснодар, август 2018 г.). — Краснодар : Новация, 2018. — С. 1-4.

4. Жураковский Г.Е. Очерки по истории античной педагогики / Г.Е. Жураковский - М.: Государственное Учебно-Педагогическое Издательство Наркомпроса PCФСР, 1940. - 110 c.

5. Вагилова В.Р. Прогрессивное развитие понятия гражданской грамотности на разных этапах развития общества // StudNet, 2020. № 9. С. 17-21.

6. Кильсенбаев Э.Р. Взгляды ученых Древней Греции на воспитание // Инновационная наука. 2016. №6-2. С. 210-212.

7. Мисюров Н.Н. «Государственное благо» и «Добродетель хорошего гражданина». Аристотель о полисной демократии // Вестник ОмГУ. 2011. №3. С. 37-40.

8. Жураковский Г.Е. Очерки по истории античной педагогики / Г.Е. Жураковский - М.: Государственное Учебно-Педагогическое Издательство Наркомпроса РСФСР, 1940. - С. 174.

9. Ц Цицерон. 06 обязанностях // Цицерон. 0 старости. 0 дружбе. 06 обязанностях / пер. В.0. Горенштейна. — М.: Наука, 1974. — С. 100.

10. Цицерон М.Т. Философские трактаты о законах. [Электронный ресурс]: http://ancientrome.ru/antlitr/t.htm?a=1414880001

11. Титаренко И.Н. Гражданственность и идеальный гражданин в учении Цицерона // Научная мысль Кавказа. 2009. №1 (57). С. 26-33.

12. Титаренко И.Н. Гражданственность и идеальный гражданин в учении Цицерона // Научная мысль Кавказа. 2009. №1 (57). С. 26-33.

(с Вагилова Внера Радиковна (vneraa@mail.ru), Гаязов Альфис Суфиянович (alfis@list.ru).

Журнал «Современная наука: актуальные проблемы теории и практики»

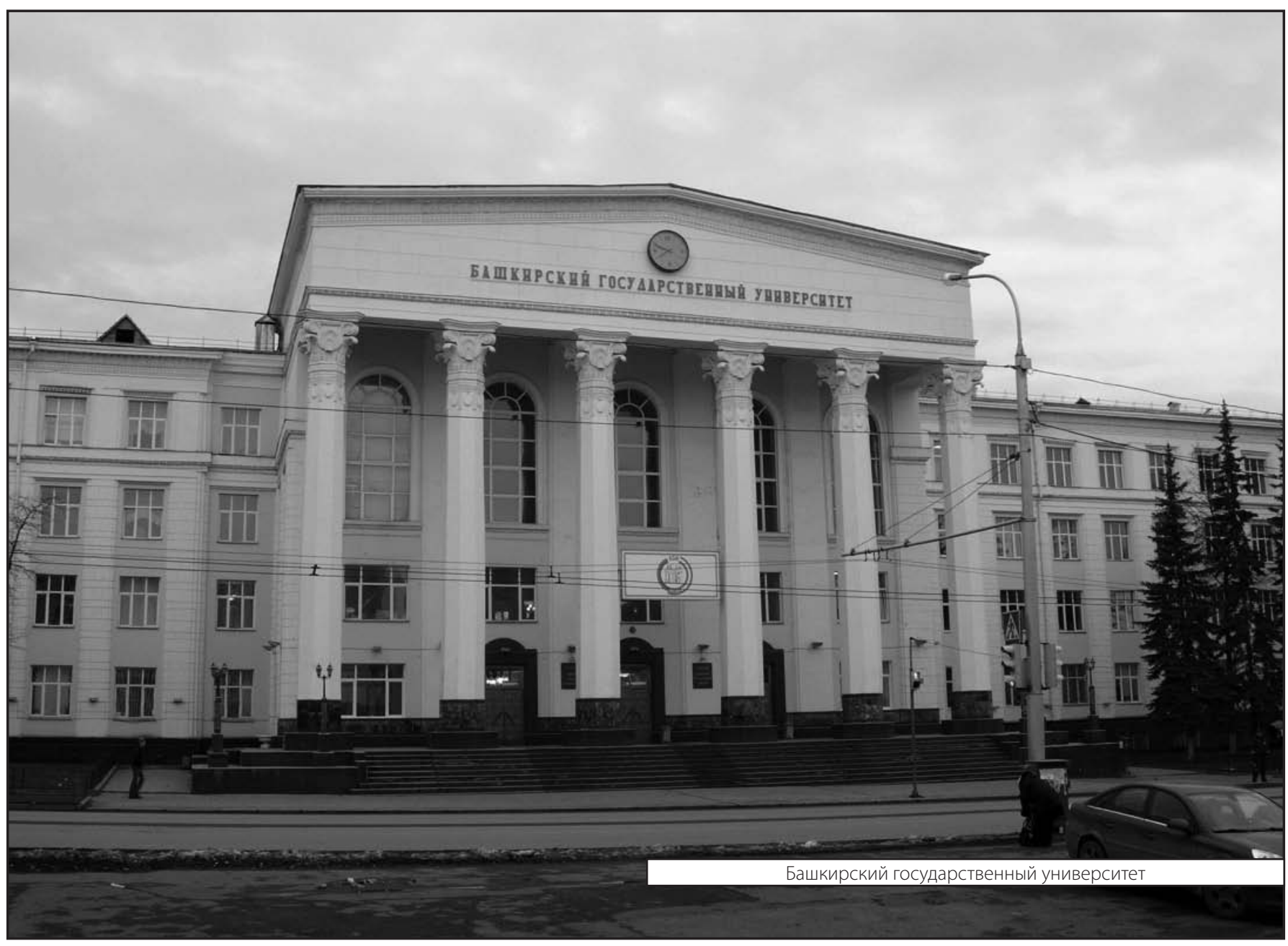

